\title{
THE "HIERARCHICAL CONSTANT" AS THE UNDERLYING PRINCIPLE OF PUBLIC-PRIVATE PARTNERSHIP*
}

\author{
UDC 330.322.16:334.72
}

\section{Predrag Cvetković}

\author{
University of Niš, Faculty of Law, Niš, Republic of Serbia
}

\begin{abstract}
Public-Private Partnership (hereinafter: PPP) is a framework of joint action involving the public sector and the private capital. The primary goal of PPP is to secure the proper operation of public services and the exercise of the public interest activities. In borderline cases, where the public interest is jeopardized as a consequence of inadequate actions of the private sector and where it is necessary to choose between the public or the private interest, the PPP is overshadowed by the hierarchical structure and methodology in public administration. In that case, the state returns to the pattern of hierarchical action stemming from the permanent right of the state to apply the interventionist paradigm (through the so-called "hierarchical constant"). Public-private partnership is also a form of moral revitalization as it generates a new kind of ethics. As the private sector gradually transforms and achieves qualitative improvements, private actors start observing their own (per se narrow) private interests through the prism of general public interests and welfare. Thus, the relationship between the public and the private sector has fundamentally changed. Once based on the hierarchical structure and administrative regulation (where the private sector was treated as a second-rate participant, which frequently triggered the private actors' reaction clearly reflecting their "misconception" of the public interest), their interrelation has been replaced by the relationship based on mutual trust and cooperation.
\end{abstract}

Key words: Public-Private Partnership, hierarchical constant, ethics, infrastructure.

Received December $14^{\text {th }}, 2016 /$ Accepted December $16^{\text {th }}, 2016$

Corresponding author: Predrag Cvetković, LL.D.

Faculty of Law, University of Niš, Trg Kralja Aleksandra 11, 18000 Niš, Republic of Serbia

E-mail: pepi@prafak.ni.ac.rs

* This paper is a result of scientific research conducted within the project "Protection of Human and Minority Rights in the European Legal Area" (179046), carried out by the Faculty of Law, University of Niš, and supported by the Ministry of Science and Technological Development of the Republic of Serbia. 


\section{INTRODUCTION}

Public-Private Partnership, hereinafter: PPP (German: Offentlich-Private Partnerschaft OPP) is a widely accepted framework of joint action involving the private sector (embodied in the state and its different emanations) and the private capital. Its primary purpose is to ensure the exercise of the public interest as well as an efficient and economically sustainable infrastructural development.

The tension between the public and the private sector and the controversy in the publicprivate partnership are generated by their conflicting interests and fundamentally different characteristics. Given its structure and the mode of operation, the former is aimed at protecting, exercising and promoting the general public interest. The latter rests on the private initiative aimed at attaining capital gains. This distinction is prima facie the fundamental obstacle in constructing the legal framework of public-private partnership which may be overcome through the process of gradual and comprehensive synchronization of these conflicting interests. In that context, the primary goal of both public and private actors is to eradicate or substantially reduce the "moral hazard" to an absolute minimum. As far as public actors are concerned, "the moral hazard" rests on the confidence and trust vested in the private actors and their propensity to commit to exercising not only their own narrow private interests but also the general public interest. On the other hand, the private actors enter the joint action assuming that they will receive a fair and equal treatment in this partnership which is principally aimed at exercising some public interest whereas the extent of observing one's private interest largely depends on the extent it serves the public interest. The degree of accomplishing this goal is also an important criterion for qualifying the legal framework of public-private partnership as either functional or dysfunctional.

The efficient operation of public-private partnership rests on two presumptions.

The first presumption is a clear and unambiguous definition of a public interest. As a matter of fact, there is an interrelatedness and interdependence between the public and the private interest. An inadequately defined public interest leads to favouring certain entities or individuals by establishing the monopoly (in the administration, economic or social relations) even in cases where the given circumstances ensure equal opportunities and sound competition between the public and the private sector (Mahoney, McGahan, Pitelis, 2009: passim).

The second presumption is coordination between the public and the private sector. Their coordination implies the presence of a clear and specific common interest (in addition to particular interests of each sector), which lays the common grounds for enacting an acceptable regulatory solution. The basic presumption of the aforesaid outcome is a high-level managing capacity in both public and private sectors alike. Whereas the managing capacity in the public sector is hardly ever disputed (at last formally), the managing capacity in the private sector grows along with the growing strength and organizational level of private actors. The strength of the private sector is defined by the actual power of its management to impact, monitor and sanction the behaviour of its shareholders, to make autonomous decisions on their behalf and to ensure the observance of these decisions.

In case the private sector does not have the relevant capacities or characteristics (e.g. a lack of efficient organization), this drawback is compensated by the hierarchical intervention of the state. The intervention does not imply that the state shall automatically, fully and without delay provide for the exercise and protection of the public interest. In fact, the contemporary society has abandoned the concept of the interventionist state, which was 
predominant until the 1970s and based on the technocratic vision of administering the public sector. Instead, modern countries have accepted the concept of the regulatory state which implies that the public interest is partly subject to the operation of the free market. The role of the state is embodied in defining the rules of the game and the structural support to private actors to accomplish their socially "opportune" outcomes. This "concession" is a result of the privatization of the public sector, leading to the process of deregulation and replacement of the interventionist paradigm by the corrective action of the free market. The regulatory state makes provisions for the inclusion of the private sector into the administration of public affairs by ensuring its interaction with the public sector at the stage of defining the public policy in a particular area as well as in the process of its implementation. Thus, the pre-set regulation goals are implemented in the process of defining the norm by which the regulation is being exercised (which is defined as "inclusion of norm targets in the norm settings process"). It eventually facilitates a higher degree of observance of legal norms governing the protection of the public interest, particularly given the fact that private partners are more likely to abide by the rules created by their direct involvement in the rule-making process than vice versa.

Yet, in borderline cases where there is a choice to be made between the public or the private interest, the PPP is overshadowed by the hierarchical structure of public administration. In that case, the state turns back to the pattern of hierarchical action stemming from the permanent right of the state to apply the interventionist paradigm (through the socalled "hierarchical constant"). It occurs in case the public interest has been jeopardized as a result of an inadequate behaviour of the private sector. The hierarchical constant and its characteristics will be discussed in the second part of this article.

\section{The Hierarchical Constant of PUblic-Private Partnership}

The competent public authorities are obliged to establish the standards governing the administration of public services and the protection of the public interest, irrespective of whether this interest is protected by the private or the public sector. This specific feature of providing public services is defined as "the hierarchical constant" of the public sector, which is also relevant in public-private partnership. ${ }^{2}$ On the other hand, the hierarchical constant shall not be used by the public authorities for the purposes of imposing a crypto-monopoly over the general public interest activities; the private sector is entitled to satisfy its own private interest in a manner which is complementary and convergent with the public interest.

The hierarchical constant ensures that the exercise of the public good though the "mediation" of the private sector does not result in excluding or imposing restrictions on legitimacy and its respective control. This legitimacy is absolutely necessary in the process of structuring and applying the PPP concept; the necessity is a result of the political sensitivity and the significance of the interests involved. Namely, the participation of private actors in exercising the public interest may potentially jeopardize the legitimacy of the action aimed at exercising such an interest; as a rule, the political public is rather skeptical towards the disposal of public resources for the benefit of private entities. The skepticism is embodied in the standpoint that the primary goal of including the private sector into the process of ensuring the public good is to generate private profit rather than satisfy the public interest. The public

\footnotetext{
${ }^{1}$ For more detailed considerations, see infra in Part 2 of this paper.

${ }^{2}$ The linguistic term, specifically referring to the "public-private" rather that the "private-public" partnership, actually reflects the hierarchical constant.
} 
sector may be exposed to a critical political pressure in case the private investor's activity is predominantly aimed at making capital gains, without demonstrating due consideration for a further development of the quality of public services (schools, hospitals, infrastructure, etc.). For this reason, it is necessary to establish the "public identity" of the interest which is achieved by means of enacting relevant regulations, establishing "the best practices" as the criteria for a successful exercise of the public good, and providing a steadfast definition of standards for establishing the public interest and its implementation. Thus, the private sector is preventively put in the position of an accountable actor. The protection of public interests and ensuring the legitimacy of private action in the public sector are based on the presumed principles of transparency and public accountability.

The primary tools for securing the public identity of a general public interest are promotion and transparency. Namely, the possibility of controlling the exercise of the public interest, which is put into effect either through administrative or political processes, is diminished by the extent to which the public good has been transposed into the domain of the private sector. For this reason, it is necessary to organize public debates (both ex ante and during the action aimed at achieving the public interest) and ensure the exercise of the principles of fairness and equality. Transparency generates a positive pressure on public authorities to constantly provide information on whether and to what extent the public interest is put into effect by the private sector (and, if not, for what reason).

Transparency per se is insufficient for securing the legitimacy of the private action. Another convergent prerequisite is to ascertain the public accountability. Public accountability is defined as responsibility not only towards the one who has delegated the power (i.e. the responsibility of the management towards shareholder, the responsibility of an agent or service provider to the principal body that authorized the agent to provide services) but also the responsibility to all the participants who bear the consequences of inadequately provided services and the failure to provide for the public good. This kind of responsibility is accompanied by the fiscal liability and "reputational" responsibility. The adequately regulated and sanctioned responsibility of the participants in the PPP relations is essential for the legitimacy of the public- private partnership.

At this point, it may be noteworthy to point out that the hierarchical constant necessarily reflects the prevailing legal and political discourse and system of values. The structure of public-private partnership is imbued with elements which are laid down by the political leadership; thus, the PPP goals are frequently no more than a reflection of political priorities of the governing elite. The elites use the public-private partnership as "an ideological safety buoy", which is deployed as an instrument for accomplishing prospective goals and justifying the changes in the legislative and political paradigm underlying the legislation (Varadi, 1999: 272-273). It is the universal "key" in which the hierarchical constant is to be interpreted as an element of public-private partnership, irrespective of the time, place, subject matter or ideological provenience. ${ }^{3}$

\footnotetext{
${ }^{3}$ In the Public-Private Partnership and Concessions Act of Republic of Serbia (Official Gazette RS, no. $88 / 2011$ ), the hierarchical constant is reflected in the act of establishing and authorizing the Public-Private Partnership Commission. See: Art. 65 of this Act, passim.
} 


\section{Public-Private PARTNERShIP AS AN ElEMENT OF Social Discourse}

The participation of the private sector in the public affairs may lead to the revitalization of the public interest and the "sacralization" of the market principle, which may involve neglecting the social component of public welfare. For this reason, the qualification of the social component in exercising the public interest, as a factor of secondary importance as compared to the promotion of the free trade principle, is a possible impediment to the adequate implementation of the public-private partnership as a legitimate social concept.

The revitalization of the public interest takes effect if the private sector behaviour is entirely based on the lucrative principle. The private sector must act not only as the provider of the public interest but also as a guarantee of equality in the access to the public good, in the way which corresponds with the public sector activities. The mechanism of transparency and public accountability serves as a corrective for the aforementioned potentially harmful outcomes. $^{4}$

\section{Public-Private PARTNERShIP AS A MODEL OF THE NEW ETHICS OF SOCIAL RELATIONS}

Public-private partnership is a form of moral revitalization (Minow, 2003: passim). Namely, as the private sector gradually transforms and makes qualitative improvements, private actors start observing their own narrow private interest through the prism of general public interest and welfare. Thus, the relationship between the public and the private sector is fundamentally changed; once based on the hierarchical structure and administrative regulation (where the private sector was treated as a second-rate participant, which frequently triggered the private actors' reaction clearly reflecting their "misconception" of the public interest), the interrelation has been replaced by the relation based on mutual trust and cooperation.

There are few areas in business relations ${ }^{5}$ where ethics is of such paramount importance as it is in public-private partnership. The major impact of PPP on the "ethical discourse" stems from the fact that public-private partnership promotes a new form of self- governance as an alternative to the traditional forms of policy-making via politically oriented bureaucracies. In that context, there is always an emphasis on the fact that the PPP concept is necessarily determined in concreto, considering that the PPP concept does not exist as a universally applicable concept ${ }^{6}$ and largely depends on the social, economic, historical, societal, legal and other contexts (Baker, Justice, 2008: passim). Yet, the need to synchronize

\footnotetext{
${ }^{4}$ For more information, see supra in Part II of this Paper.

${ }^{5}$ In practice, there are obvious examples where the PPP has "regenerated" the business ethics by drawing the state closer to the free market, either as a regulator or as an entrepreneur. For example, when the government of Great Britain denationalized the infrastructural facilities in the 1980s, the stocks/shares were being sold below the nominal value; the reason for this approach was not the Government's tendency to liberalize the public sector (as the existing regulatory framework remained in force) but its determination to enable the private sector a direct access to an important part of the national economy. Thus, the managers of public companies had to "step into the entrepreneurs' shoes" and resolve the issues generated in relations with new stock holders (private entrepreneurs who demanded that the public companies be managed by applying the business management strategies which they would be using as participants on the market). In this case, the acceptance of the market business ethics, without the immediate protection of the public sector, is considered to be a direct effect of applying the PPP concept. For more information, see: (Starr, 1988: 13-14).

${ }^{6}$ The only exception is the preconditioning of the PPP goals by the political orientation of the governing class. See: supra footnote 4 and the accompanying text.
} 
the interests of the public and the private sector remains the common denominator of publicprivate partnership perceived in generic terms. The synchronization must be based on certain ethical principles which are sublimated in a "third", mixed dimension of public-private partnership which has emerged as a result of intertwining the public and the private interests (and accordingly, interconnecting private and public actors).

The authentic PPP ethics is also supported by the standpoint that the contracts it rests on are classified as co-called "relational" contracts (long-term contracts). These contracts are based on the presumption that there are common values which the contracting parties are likely to pursue. Such values are perceived as an ethical category, being "the key" for interpreting the provisions of the long-term agreement (involving the permanent performance of liabilities). The explicit inclusion of ethical principles in the process of interpretation of a PPP-based contract lays down a consistent legal framework which is vibrant enough to preserve the entire structure in the circumstances of tension emerging between the public and the private sector during the implementation of the PPP concept; this tension is of a sui generis nature because it does not and may not appear in that form either in public law agreements or in private law contracts. ${ }^{7}$

The standpoint on ethics as the connecting factor between economy and the public good has its stratum in the hypothesis that the behaviour in line with the moral norms does not only lead to exercising the general public interest but also to self-realization. As corporations are constituted of individuals, promoting the ethical conduct and righteous action contributes to the development of human potentials (of individual employees) and brings more benefits to the respective company. Therefore, the selfless conduct and commitment to the common good is the core interest of the business community; the economic sector is not ethically neutral, nor inherently inhuman or incompatible with the society. It is part of the general corpus of human activities, for which reason it has to be structured and managed in observance of both human and ethical standards.

The ethical issue raised in public-private partnership seems to be much more controversial when it comes to private partnership. ${ }^{8}$ The corporate social responsibility is an important institute for defining the structure and the contents of ethics in private partnership. The basic feature of this institute is articulated in the assumption on the social function of property. Thus, the exclusive property rights may be justified: "first, because every man is more careful to procure what is for himself alone than that which is common to many or to all; secondly, because human affairs are conducted in a more orderly fashion if each man is charged with taking care of some particular thing himself, whereas there would be confusion

\footnotetext{
${ }^{7}$ For more information see: (Diathesopoulos, 2010: passim). The concept of relational contracts is based on the theory which was developed in the USA a few decades ago. The idea was first presented in a conference by Prof. Ian Roderick Macnail in 1967 but the first article on this issue "Whither Contracts" was published in 1969. This theory is predominantly the subject matter of analysis in the legal systems based on the Anglo-Saxon legal tradition and, to a certain extent, it challenges the legal formalism. It is based on the assumption that contracts must necessarily be observed by taking into account the relational elements of the context they operate in, for which reason the analysis of a contract may not be based on the presumption that the contract ex ante entirely regulates certain legal relation. The significance of the wider "discourse" in which certain contract operates is not identical in all contracts. Its impact is more substantial in contracts based on a specific social and economic context as well as on the open intuitu personae relationship between the contracting parties, in which case the aforesaid circumstances influence the scope and content of the specific contract. This theory has a significant impact on the economic literature, which is based on the assumption that even the simplest transaction implies certain liabilities, all of which depends on a wider social and economic context. See: (Macneil, 1985: passim).

${ }^{8}$ The public actor preserves the public interest even though the political elites frequently use the PPP as an instrument for accomplishing their own interests. See: (Varadi, 1999: passim).
} 
if everyone had to look after any one thing indeterminately; finally, quarrels (conflicts) arise more frequently where there is no division of the things possessed."

Moreover, the business ethics of PPP must promote the competitive social justice rather than abstract institutional justice. It must determine and, where necessary, transform every commercial transaction. Thus, justice (including social justice) becomes the global characteristic of business activities, where the PPP concept has a significant role.

The private actor has both the right and the duty to act as a subsidiary facilitator of social ethics in the circumstances when there is "an absence of public management". This standpoint is fully reflected in the PPP concept, where the private partner must observe his own activities in light of the need to protect not only his own particular interest but also the general public interest. In that context, there seems to be some justification for the following argument: the greater the economical power of a private actor, the larger his duty to contribute to the common good. Certainly, there are limits to this obligation. In defining this obligation, a clear distinction must be made between what is considered to be an individual virtue (on the one hand) and what is considered to be a social duty (on the other hand), which is perceived as a socially responsible business activity of private actors. ${ }^{10}$

\section{REFERENCES}

1. Baker, K., Justice, J. (2008). The Institutional Design of Self-governance: Insight from Public-private Partnerships. Queensland University of Technology, Brisbane, Australia 26-28 March 2008.

2. Diathesopoulos, M. (2010). Relational contract theory and management contracts: A paradigm for the application of the Theory of the Norms. Lancaster University Law School Research Papers , June 15, 2010.

3. Dierksmeier, C., Celano, A. (2012). Thomas Aquinas on Justice as a Global Virtue in Business. Business Ethics Quarterly 22(2). 247-272.

4. Kohls, J., Christensen, S. L. (2002). The Business Responsibility for Wealth Distribution in a Globalized Political Economy: Merging Moral Economics and Catholic Social Teaching. Journal of Business Ethics. 35(3). 223-234.

5. Macneil, I. R. (1985). Relational contract: what we do and do not know. Wisconsin Law Review. 483-525.

6. Mahoney, J. T., McGahan, A. M., Pitelis, C. N. (2009). The Interdependence of Private and Public Interests. Organization Science. 2(6). 1034-1052.

7. Minow, M. (2003). Public and Private Partnerships: Accounting for the New Religion. Harvard Law Review. 116. 1229-1270.

8. Paul Starr, P. (1988). The Meaning of Privatization. Yale Law and Policy Review. 6. 6-41.

9. Varady, T. (1999). The Emergence of Competition Law in (Former) Socialist Countries. The American Journal of Comparative Law. 47 (2). 229-275.

\footnotetext{
${ }^{9}$ As an illustration, some authors provide a justification for the exclusive right to private property which was first elaborated by Thomas Acquinas. See: (Dierksmeier, Celano, 2012: passim).

${ }^{10}$ Thomas Aquinas illustrated the difference between the virtue and the duty by analyzng the moral dilemma of a grain merchant. The basic question is whether the grain merchant, having been fully aware of the impending rise in demand and a subsequent decline in prices, should fully disclose the information to his customers, or whether he could legitimately profit from their ignorance and capitalize on the asymmetry of information. While it is unlawful to incur any damage or loss to another, this prohibition does not encompass the duty "to give another the help or advice which would be of some competitive advantage". A single person is highly unlikely to take into account the interests of all participants in business; such a requirement would be unethical. Mutatis mutandis, the described moral dilemma is present even today in defining the contents of the PPP legal framework. The basic question is how the private partner should be convinced (even in spite of his habitus) to take into account not only his own private interest but also the public interest. For more information, see: (Kohls, Christensen, 2002: passim).
} 
"HIJERARHIJSKA KONSTANTA"

\section{KAO TEMELJNI PRINCIP JAVNO-PRIVATNOG PARTNERSTVA}

Javno-privatno partnerstvo predstavlja okvir zajedničke akcije javnog sektora i privatnog kapitala sa ciljem obezbeđenja funkcionisanja delatnosti od opšteg interesa. JPP u graničnim situacijama (u slučaju ugrožavanja javnog interesa zbog neodgovarajućeg postupanja privatnog sektora, kada je neophodno opredeliti se za javni ili privatni interes) ostaje u senci hierarhije: tada se država vraća na obrazac hijerarhijskog postupanja, permanentno zadržavajući pravo (kroz tzv. ,hijerarhijsku konstantu“) da primeni intervencionističku paradigmu. Javno-privatno partnerstvo predstavlja vid moralne regeneracije i kreira novu etiku: naime, privatni sektor postepeno ostvaruje kvalitativni skok i sopstveni, per se uski privatni interes sagledava kroz prizmu javnog dobra. Time se fundamentalno menja i odnos javnog $i$ privatnog sektora. Odnos hijerarhijske i komandne regulative (pri čemu je privatni sektor tretiran kao subjekt drugog reda, što je neretko razlog za reakciju privatnog sektora manifestovanu kao nerazumevanje javnog interesa) menja se odnosom poverenja i koperacije.

Ključne reči: javno-privatno partnerstvo, hijerarhijska konstanta, etika, infrastruktura. 